Agro-Science Journal of Tropical Agriculture, Food, Environment and Extension Volume 20 Number 3 (July 2021) pp. $71-79$

ISSN 1119-7455

\title{
OUTPUT RESPONSE AT THE FARM LEVEL: MAIZE SUPPLY AND INPUT DEMAND IN KADUNA STATE, NIGERIA
}

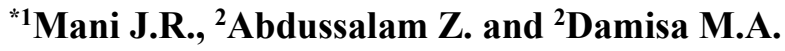 \\ ${ }^{1}$ National Agricultural Extension Research \& Liaison Services, \\ Ahmadu Bello University, Zaria, Nigeria \\ ${ }^{2}$ Department of Agricultural Economics \& Rural Sociology, \\ Ahmadu Bello University, Zaria, Nigeria \\ *Corresponding author’s email: jrmani2001@yahoo.com
}

\begin{abstract}
The degree of responsiveness of agricultural supply to input either in the short or long-term production decision is crucial in understanding the role of price and non-price factors in increasing supply. This study analysed output supply and input demand of maize production using a farm survey data of 600 randomly selected maize farmers from all agricultural zones in Kaduna State of Nigeria. Data were analysed using a modified Nerlovian model and set of input demand equations. The results showed that in all estimates (yield and hectarage) long run estimates are greater than the short run values and both were inelastic. The elasticity for lagged own price of maize was $0.23 \%$ in the short run and $0.17 \%$ in the long run were positive, marginal and inelastic. The hectarage elasticity of supply response for maize is 1.04 in the short run and 0.78 in the long run. The result of the input demand equations showed that the coefficients cost of agrochemical and farm size statistically affect seed, fertilizer and labour demand. The study portrayed that the most critical issues in maize supply are the lack of improved production technology, poor capital investment, land unavailability or poor land tenure system and poor policy incentives. The study recommends that, there is a need for State policy on agricultural research and extension, and adequate input price policies. The government is advised to dissolve the agricultural extension service system to local governments. This will allow agricultural extension system to be more location specific.
\end{abstract}

Key words: hectarage, short run, long run, demand, yield

\section{INTRODUCTION}

Smallholder farmers in Nigeria face the dual problems of food insecurity and poverty. To address these issues, the Federal Government adopted the modern food systems approach through the Agricultural Transformation Agenda (ATA) in 2012. Of particular interests are agricultural value chains (AVCs) that link production with processing, storage, marketing, distribution and consumption of agricultural products (Mulford, 2013; Ajani and Igbokwe, 2014). Maize as one of the three most important cereals grown in Nigeria, was a priority crop under the flagship of ATA since 2012. The transformation action plan was to be carried out through its value chain, while recognizing the roles of actors and stakeholders along the nodes of the chain, input requirements in achieving production targets, constraints faced and expected output. The main target was to grow the agricultural sectors, generate employment opportunities and achieve economic development (Federal Ministry of Agriculture and Rural Development, 2011).
According to Babu et al. (2014), commercialization of agriculture is a part of market-oriented development, encouraging better use of resources for agricultural supply. Supply response thus, represents changes in agricultural output due to a change in agricultural input prices (seeds, fertilizer and agro-chemicals) and non-price (land, access to market and household demographic characteristics) factors as they relate to each other. It follows then that supply response has policy implications in that if long run elasticities of supply are greater than unity, it provides strong validity for the argument that low real farm prices are important reason for low productivity or supply and incomes particularly in rural areas (Rudaheranwa et al., 2003).

Also, Nerlove (1979) noted that agricultural pricing policy plays a key role in increasing both farm production and incomes, and that supply response is fundamental to an understanding of this price mechanism. Supply response results enhance an understanding of the impacts that alternative policy packages may have on households' production 
activities and market participation. Studies abound on aggregate supply response, not on individual crop response. Most studies of supply response are based on time-series data, and use the Nerlove (1958) model for single commodities or Griliches' (1960) method for aggregate supply response. Both models are usually applied by estimating a single equation independently for each commodity, or group of commodities (if aggregate), without characterizing linkages between them via a matrix of cross-price elasticities. Comprehensive reviews by Askari and Cummings (1977), Braulke (1982), Hallam and Zanoli (1992), Diebold and Lamb (1997), and Rao (2007) gave more insights to the above assertion.

The theoretical literature of supply response assumes that economic agents, notably, farmers respond to the relevant price and non-price variables (Boughton et al., 2007). This is following the neoclassical theory which postulates perfect competition in the market; that prices are the most efficient system of information and incentives; adjustment is fairly smooth through price signals. Individual crop elasticities are needed for policy analysis and available empirical results of studies so far indicate that individual crops do respond strongly to price factors, often with higher price elasticity than aggregate agricultural output (Kwanashie et al., 1998).

In developing countries, Farooq et al. (2001) indicated that uncertainty flourish the precise role and impact of agricultural policies. This is partly attributable to the lack of farm-level analysis of the effects of policies (especially relating to prices) on the supply response of mostly peasant farmers (Abrar et al., 2004). Accordingly, Nkang et al. (2007) noted that the measurement of supply responsiveness of farmers is a veritable means of assessing the impact of economic reforms with a view that policies, which provide appropriate incentive such as price or non-price factors are likely to bring about high supply responsiveness, while those that act as disincentives are less likely to do so. Problems of uncertainty, price instability, access to markets and week coordination between the various stages in food supply chain pose major challenges for the farming community as well as policy makers. Therefore, one of Nigeria's major challenges is to identify and put in place policies, institutions and investments that will enable agricultural systems to catalyse productivity growth on the millions of smallholder farmers in the country. Consequently, any change in factor and product prices affects the factor demand and output supply simultaneously since output supply and factor demand are closely interlinked to each other.

To formulate effective price and food-security policies, there is a need for reliable empirical knowledge about the degree of responsiveness of input demand and crop output supply. Hence, the degree of responsiveness of agricultural supply to inputs either in the short- or long-term production decision is crucial in understanding the role of inputs, prices and non-price factors in increasing supply, which may also constitute a further issue for policy formulation. This study estimated the maize supply response of non-price factors of production and output as well as the input demand functions on maize in Kaduna State.

\section{MATERIALS AND METHODS Study Area}

This study was conducted in Kaduna State. The state has 23 local government councils, located between latitudes $9^{\circ} 03^{\prime} \mathrm{N}$ and $11^{\circ} 32^{\prime} \mathrm{N}$ of the equator and between longitudes $6^{\circ} 05^{\prime} \mathrm{E}$ and $8^{\circ} 48^{\prime}$ $\mathrm{E}$ of the prime meridian. It has a population of about 6,113,503 (National Population Commission, 2006) and estimated to increase to about 8, 645, 035 by 2017 based on the National Population Commission annual growth rate of $3.18 \%$. Kaduna state is an agrarian state. The state is the leading producer of maize in Nigeria, with an annual production of about 795, 590 metric tonnes in 2016 (NAERLS and FMARD, 2017), producing about $22 \%$ of the country's total maize production.

\section{Sampling Procedure and Data Collection}

The Kaduna state Agricultural Development Programme (KADP) has divided the state into four agricultural zones. Following this structure, the study employed a purposive sampling technique was employed for the selection of two local government areas (LGAs) from each of the zones: Soba and Giwa from (Maigana zone), Birnin-gwari and Chikun (Birnin gwari zone), Lere and Igabi (Lere zone), Jaba and Kagarko (Samaru zone), giving a total of eight LGAs. The choice of these selections was based on the prevalence of maize farmers in the areas according to the KADP village listings of 2016. In the third stage, four communities were purposively selected from each of the selected LGAs making a total of 32 communities, based on the KADPs' main coverage areas. In the fourth stage, a proportionate $(10 \%)$ random sampling of each of the LGAs was used as the sample size. A total of 99 respondents were selected from Samaru zone, 194 in Lere, 159 in Birnin-gwari and 147 in Maigana zone. This gives a grand total of 600 respondents. The sampling procedure and sample size are summarized in Table 1.

Table 1: Selected LGAs and sample size of farmers

\begin{tabular}{llcc}
\hline KADP zone & LGAs & Sample frame & Sample size \\
\hline Samaru & Jaba & 390 & 39 \\
& Kagarko & 600 & 60 \\
Lere & Igabi & 1090 & 109 \\
& Lere & 860 & 86 \\
Birnin-gwary & Birnin-gwari & 650 & 65 \\
& Chikun & 940 & 94 \\
Maigana & Soba & 730 & 73 \\
& Giwa & 740 & 74 \\
Total & & & 600 \\
\hline
\end{tabular}




\section{Analytical Techniques \\ Estimating Maize Supply Response}

Ordinary least squares (OLS) technique was used to estimate the parameters of the Nerlovian partial adjustment model. The estimating equations were expressed in logarithmic form. From the adjustment lag model and following the work of Nkang et al. (2007) and Munyati et al. (2013), the yield response relationship in this study was estimated as:

$\ln M_{t}=\beta_{0}+\beta_{1} \ln M_{t-1}+\beta_{2} \ln P_{m, t-1}+$ $\beta_{3} \ln P_{s g, t-1}+\beta_{4} \ln H_{m, t-1}+\beta_{5} \ln P_{s, t-1}+$ $\beta_{6} \ln P_{a c, t-1}+\beta_{7} \ln P_{\text {fer }, t-1}+\beta_{8} \ln P_{l, t-1}+$ $\beta_{9} \ln R_{t-1}+\beta_{10} \ln R_{1}+\beta_{11} \ln R_{2}+\beta_{12} \ln R_{3}+$ $\beta_{13} \ln R_{4}+U_{t}$

where $M_{t}$ is maize output in year $t(\mathrm{~kg}) ; M_{t-1}$ is maize output year $t-1(\mathrm{~kg}), P_{m, t-1}$ is price of maize in year $t-1(\mathrm{~N}), P_{s g, t-1}$ is price of sorghum in year $t-1(\mathrm{~N}), H_{m, t-1}$ is maize hectarage under cultivation year $t-1$ (ha), $P_{s, t-1}$ is quantity of seeds in year $t-1$ $(\mathrm{kg}), P_{a c, t-1}$ is quantity of agrochemicals in year $t$ 1(L), $P_{\text {fer }, t-1}$ is quantity of fertilizer in year $t-1$ (kg), $P_{l, t-1}$ is labour in year $t-1$ (man hour), $R_{t-1}$ is amount of rainfall in year $t-1, R_{1}$ is distance to the nearest market (kilometres), $R_{2}$ is farmer's level of education (number of years of formal schooling), $R_{3}$ is age of farmer (years), $R_{4}$ is household members partaking in maize production (number), and $\ln$ is natural $\log , U_{t}$ is random disturbance term. The simplified hectarage response function is given as:

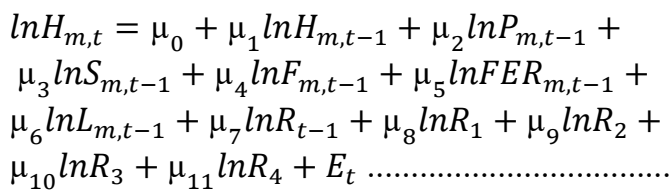

where $H_{m, t}$ is maize hectarage under cultivation in year $t$ (ha), $M_{t-1}$ is maize hectarage under cultivation in year $t-1$ (ha), $P_{m, t-1}$ is price of maize in year $t-1$ $\left.\mathrm{kg}^{-1}\right), S_{m, t-1}$ is quantity of seeds in year $t-1(\mathrm{~kg}), F_{m, t-1}$ is quantity of agrochemicals used in year $t-1$ (L), $F E R_{m, t-1}$ is quantity of fertilizer used in year $t-1(\mathrm{~kg}), L_{m, t-1}$ is labour in year $t-1$ (man hour), $R_{t-1}$ is amount of rainfall in year $t-1, R_{l}$ is distance to the nearest market (kilometres), $R_{2}$ is farmer's level of education (number of years of formal schooling), $R_{3}$ is age of farmer (years), $R_{4}$ is household members partaking in maize production (number), $\ln$ is natural log, and $E_{t}$ is random disturbance term.

Utuk (2014) indicated that both the long and short run elasticities can be derived from the Nerlovian supply response model. Specifically, the long run elasticities are calculated as follows:

$$
E=\frac{\mu_{i}}{1-\beta_{1}}
$$

where $E$ is long run elasticity, $\mu_{i}$ is short run elasticity, and $\beta_{1}$ is coefficient of the lagged dependent variable. The input demand equations are explicitly stated as follows:

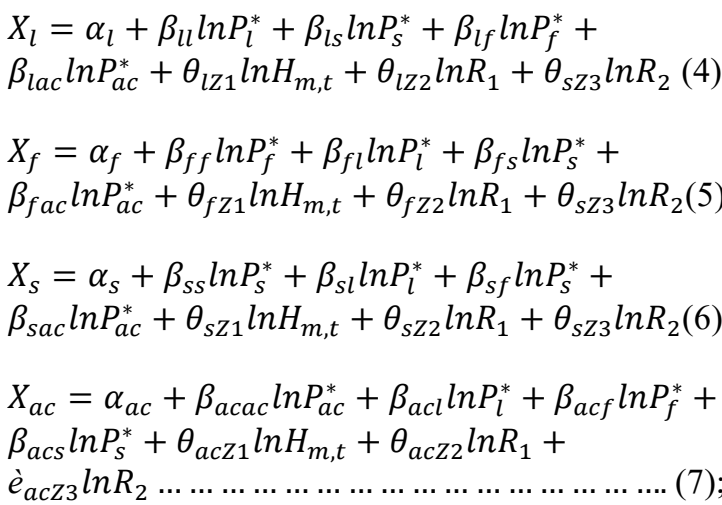
where $X_{l}$ is labour (man hour), $X_{f}$ is fertilizer $(\mathrm{kg})$, $X_{s}$ is seeds $(\mathrm{kg}), X_{a c}$ is agrochemicals (L), $P_{f}$ is price of fertilizer ( $\mathrm{kg}^{-1}$ ), $P_{l}$ is labour (wage rate in per man hour), $P_{s}$ is price of seeds $\left(\mathrm{kg}^{-1}\right), P_{a c}$ is price of agrochemicals ( $/ \mathrm{kg}), H_{m, t}$ is land area under maize (ha), $R_{l}$ is distance to the nearest market $(\mathrm{km}), R_{2}$ is farmer's education level (number of years of formal schooling), $M$ is stochastic disturbance term, and $\alpha, \beta$ and $\theta$ are parameters to be estimated.

\section{RESULTS AND DISCUSSION \\ Yield Response Estimation}

Estimates of the structural parameters for the yield response equation are presented in Table 2. The explanatory power of the equation $\left(R^{2}\right)$ indicates that $63.81 \%$ of the variance in yield was predicted by the variables included in the model. The data had significant trend $f$-value of 85.80 which is significant $(p<0.001)$. Further, the trend indicates that the predictor variables provide information about the output supply response. Outcome of the analysis illustrates that the coefficients quantity of maize lagged one year $\left(M_{t-1}\right)$, price of maize $\left(P_{m, t-1}\right)$, quantity of seeds $\left(P_{s, t-l}\right)$, quantity of fertilizer $\left(P_{\text {fer }, t-l}\right)$, labour $\left(P_{l t-l}\right)$ and farm size lagged one year $\left(H_{m, t-l}\right)$ were all statistically significant at $1 \%$ probability level.

Maize yield lagged one year had a significant negative effect on maize production, suggesting that a decrease in yield in the previous year will be followed by an increase in maize yield in the next season. Though this outcome tends to deviate from the hypothesis of Nerlove's partial adjustment model. That is, farmers do not adjust their yield instantaneously to changes in prices and technology; they adjust to the optimum yield level over time. There is, therefore, an indication of maize farmers adjusting and reallocating their currently available resources to adopt or discard (as the case may be) packages of improved inputs and cultural practices. Similar results were obtained by Leaver (2004) and Ogazi (2009) in measuring the supply response function of rice in Nigeria and tobbaco in Zimbabwe, respectively. 
Table 2: Regression analysis for yield supply response

\begin{tabular}{|c|c|c|c|c|}
\hline Variable & Parameter & Coefficient & Standard error & $t$-value \\
\hline Constant & $\beta_{0}$ & $6.6759 * * *$ & 0.4829 & 13.82 \\
\hline Maize output $\left(M_{t-I}\right)$ & $\beta_{1}$ & $-0.3304 * * *$ & 0.0818 & -4.04 \\
\hline Price of maize $\left(P_{m, t-1}\right)$ & $\beta_{2}$ & $0.2307 * * *$ & 0.0840 & 2.75 \\
\hline Price of sorghum $\left(P_{s g, t-1}\right)$ & $\beta_{3}$ & -0.0382 & 0.0264 & -1.45 \\
\hline Land size $\left(H_{m, t-1}\right)$ & $\beta_{4}$ & $1.0307 * * *$ & 0.0579 & 17.82 \\
\hline Quantity of seeds $\left(P_{s, t-1}\right)$ & $\beta_{5}$ & $0.0829 * * *$ & 0.0161 & 5.14 \\
\hline Quantity of agrochemicals $\left(P_{a c, t-I}\right)$ & $\beta_{6}$ & -0.0708 & 0.0826 & -0.86 \\
\hline Quantity of fertilizer $\left(P_{f e r, t-1}\right)$ & $\beta_{7}$ & $0.1007 * * *$ & 0.0222 & 4.53 \\
\hline Labour $\left(P_{l, t-l}\right)$ & $\beta_{8}$ & $0.2197 * * *$ & 0.0482 & 4.56 \\
\hline Amount of rainfall $\left(R_{t-1}\right)$ & $\beta_{9}$ & 0.0136 & 0.0267 & 0.51 \\
\hline Distance to market $\left(R_{I}\right)$ & $\beta_{10}$ & -0.0150 & 0.0282 & -0.53 \\
\hline Farmer's level of education $\left(R_{2}\right)$ & $\beta_{11}$ & 0.02219 & 0.5334 & 0.04 \\
\hline Age of farmer $\left(R_{3}\right)$ & $\beta_{12}$ & 0.0808 & 0.1158 & 0.70 \\
\hline $\mathrm{HHmmP}\left(R_{4}\right)$ & $\beta_{13}$ & -0.0015 & 0.0174 & -0.11 \\
\hline$R^{2}$ & 0.6381 & & & \\
\hline$F$ & $85.80 * * *$ & & & \\
\hline $\bar{R}^{2}$ & 0.6301 & & & \\
\hline
\end{tabular}

The coefficients of price of maize $\left(P_{m, t-1}\right)$ was found to be positive and significant $(p<0.001)$. This result is an indication that when price of maize increases by $1 \%$, average maize yield response increases by proportion of $0.23 \%$. This shows that an increase in the previous price of maize price induce the farmer to produce more maize the following year. This is an indication of price responsiveness of the farmers in the study area. This is in consonance with the findings of Alabi (2008), that reported the prices of maize and sorghum lagged one year to have a positive and significant influence on the output supply of the two cereals in the subsequent years. Price of sorghum as a competing crop was found to be negative to maize yield response and statistically insignificant this outcome is in line with a priori expectation because sorghum and maize are complementary and they compete for inputs. Consequently, an increase in the price of sorghum will lead to farmers switching to the production of sorghum. The result is in conformity with the findings of Ogundari (2018), that an increase in the price of yam increases maize supply significantly.

Furthermore, yield response to labour is positive and significant. This is also expected because maize is a labour-intensive crop placing a high demand on labour. This result is in accordance with the result of Duniya (2014) who reported that the coefficient of labour was positive and statistically significant in acha (hungry rice) farming in Kaduna State. Labour is a major input in subsistence farming and largely determines the amount of land a farmer cultivates each farming season. Labour shortage is most critical at the time of land preparation, especially ridging which takes place during the peak period of labour demand (Leonardo et al., 2015). While labour is underemployed for the best part of the year, it is in shortage at the peak of the cropping seasons. In economic theory this has been termed 'rural labour shortage in the labour surplus economy'. Low returns to labour, labour productivity and poor yields are central to household poverty.
On the other hand, the changes in quantity of seeds used in the previous year were positive and responsive to maize yield. In essence, seeds must be rationally used to maximize yield, reduce maize vulnerabilit to pests and diseases. On the contrary, insufficient use of seeds may decrease yield, as such farmers may increase their maize production by following recommended practices to avoid over utilization of inputs. Owoeye et al. (2017) found a significant positive relationship between seed use and maize production in Ekiti State, Nigeria.

The coefficient of land size was also positive. That is, a $1 \%$ increase in land under maize would cause about $1.03 \%$ increase in yield. The result is consistent with Alwan and El-Habbab (2002) and Oladejo and Ladipo (2012) in their studies with maize. According to the report of the United States Department of Agriculture (2013), Nigeria recorded an increase of over $44 \%$ of maize production in the immediate past decade, due more to increase in land area under maize than to increases in its yield.

Quantity of fertilizer used to grow maize was also positive and significant at $p \leq 0.01$. There is therefore an indication that better availability and improved fertilizer use can result in higher quantity of maize supplied. In a study by Shehu et al. (2017), quantity of fertilizer use and maize output was positive and significant indicating that fertilizer was a major determinant of the output in Bauchi State, Nigeria. Similarly, Obike et al. (2016) reported fertilizer use as a significant determinant of output among cocoa farmers in Abia State.

\section{Hectarage Response Estimation}

The result of the estimates from the hectarage response showed that $58.99 \%$ of the variation of maize hectarage is explained by the variables included in the model, with lagged maize output $\left(M_{t-1}\right)$, land size $\left(M_{t-1}\right)$, price of maize $\left(P_{m, t-1}\right)$, price of sorghum $\left(P_{s g, t-1}\right)$ and quantity of agrochemicals $\left(P_{a c, t-1}\right)$ being significant at $p \leq 0.01$ or 0.05 . All other coefficients were not significant. 
Table 3: Regression analysis for hectarage response to maize supply

\begin{tabular}{|c|c|c|c|c|}
\hline Variables & Parameters & Coefficient & Standard error & $t$-value \\
\hline Constant & $\mu_{0}$ & -1.6186 & 0.7315 & -2.21 \\
\hline Maize output $\left(M_{z, t}\right)$ & $\mu_{1}$ & $-0.0739 * * *$ & 0.0177 & -4.17 \\
\hline Maize hectarage $\left(M_{t-l}\right)$ & $\mu_{2}$ & $0.7063 * * * *$ & 0.0422 & 16.72 \\
\hline Price of maize $\left(P_{m, t-1}\right)$ & $\mu_{3}$ & $0.3467 * * * *$ & 0.1024 & 3.39 \\
\hline Price of sorghum $\left(P_{s g, t-1}\right)$ & $\mu_{4}$ & $0.1859 * * * *$ & 0.0931 & 2.00 \\
\hline Quantity of seeds $\left(S_{m,-t-l}\right)$ & $\mu_{5}$ & 0.0170 & 0.0115 & 1.47 \\
\hline Quatity of agrochemicals $\left(F_{m, t-1}\right)$ & $\mu_{6}$ & $0.0546^{* *}$ & 0.0282 & 1.94 \\
\hline Quantity of fertilizer $\left(F E R_{t-1}\right)$ & $\mu_{7}$ & -0.0054 & 0.0269 & -0.2 \\
\hline Quantity of labour $\left(L_{m t-l}\right)$ & $\mu_{8}$ & 0.0327 & 0.0349 & 0.94 \\
\hline Amount of rainfall $\left(R_{t-l}\right)$ & $\mu_{9}$ & 0.0203 & 0.0187 & 1.08 \\
\hline Distance to market $\left(R_{I}\right)$ & $\mu_{10}$ & -0.0037 & 0.0157 & -0.23 \\
\hline Farmer's level of education $\left(R_{2}\right)$ & $\mu_{11}$ & 0.0038 & 0.0049 & 0.77 \\
\hline Age of farmer $\left(R_{3}\right)$ & $\mu_{12}$ & -0.0319 & 0.0886 & -0.36 \\
\hline $\mathrm{HHmmP}\left(R_{4}\right)$ & $\mu_{13}$ & -0.0283 & 0.0244 & -1.16 \\
\hline$R^{2}$ & 0.5899 & & & \\
\hline$F$ & $64.85 * * *$ & & & \\
\hline $\bar{R}^{2}$ & 0.5808 & & & \\
\hline
\end{tabular}

The estimated parameter for price of maize has a positive sign, which is consistent with a priori expectation and theory of production: positive supply response to own price. A rise in current period price of an agricultural crop will lead to an increase in production in the next period. This assertion thus, indicates that maize prices influence the farmers' decision in terms of the amount of land allocated to maize in the current season. This negates the findings of Shoko et al. (2016) in an estimate of the supply response of maize in South Africa. The authors showed that non-price incentives such as rainfall and technology seem to have more effect on maize supply than price incentives in South Africa. Whereas the coefficient of price of sorghum as a competing crop is positive, this negates a priori expectation, where the cross elasticity of a substitute good was said to be negative. Possible explanation that could be advanced for this outcome is that small holder farmers in Kaduna State adopted inter-cropping where maize and sorghum compete for the same input (land) within the same season. The implication of this is that where resources (land) devoted to maize production are constrained relative to sorghum production, this could lead to a fall in sorghum supply and vice versa.

On the other hand, maize output lagged one year had a negative coefficient, meaning that whenever there is an increase in yield, farmers respond to this by decreasing land share to maize in the next season. This is probably because increase in yield supply may cause glut in the markets and hence farmers respond to this by reducing the share of land allocated to maize farming in the next season. This is in line with the economic theory of supply and demand. The coefficient lagged area of maize was positive and large, revealing a hectarage response. This indicates that previous hectarage allocated to maize has a significant influence in contemporary allocation of land to maize. Thus, farmers allocate land to maize production based on previous allocation. This is a reasonable finding, considering the scarcity of land and uncommon practice of crop rotation prevalent in Kaduna state. This agrees with the conclusions of Kavinya and Phiri (2014) who stated that a previous hectare allocated to maize exerts significant influence in current allocation of land to maize in Malawi.

The coefficient of agrochemical revealed that $1 \%$ increase on the availability of agrochemicals induced a $0.055 \%$ change in the next crop season hectarage allocation to maize. Therefore, timely availability and affordability of agrochemicals can upsurge hectarage allocation to maize production and consequently increase yield. Omotesho et al. (2016) found a correlation between agrochemical use and farm size in Osun state, Nigeria.

\section{Estimated Elasticity}

The short and long run elasticities for both the yield and hectarage supply responses are shown in Tables 4 and 5, respectively. From Table 4, the elasticity for lagged own price was positive and inelastic. A $1 \%$ increase in the price of maize output would lead to an expansion of the output by $0.23 \%$ in the short run and by $0.17 \%$ in the long run. This implies a gradual response of maize output to changes in price, such that maize producers were marginally responsive to maize price changes both in the short and long run. This outcome agrees with Obayelu and Ebute (2016) who found that cassava supply is positive and price inelastic in the short run.

Table 4: Elasticity of yield response

\begin{tabular}{lcc}
\hline Variable & $\begin{array}{c}\text { Short run } \\
\text { elasticity }\end{array}$ & $\begin{array}{c}\text { Long run } \\
\text { elasticity }\end{array}$ \\
\hline Price of maize & 0.2307 & 0.1734 \\
Price of sorghum & -0.0382 & -0.0287 \\
Land size & 1.0307 & 0.7747 \\
Quantity of seeds & 0.0829 & 0.0623 \\
Quantity of agrochemicals & -0.0708 & -0.0532 \\
Quantity of fertilizer & 0.1007 & 0.0757 \\
Labour & 0.2197 & 0.1651 \\
Amount of rainfall & 0.0136 & 0.0102 \\
Distance to market & -0.0150 & -0.0113 \\
Farmer's level of education & 0.0222 & 0.0167 \\
Age & 0.0808 & 0.0607 \\
HHmmP & -0.0015 & -0.0011 \\
Coefficient of adjustment & & 1.3304 \\
\hline
\end{tabular}

Source: Author's calculation 
Table 5: Elasticity of hectarage response

\begin{tabular}{|c|c|c|}
\hline Variable & $\begin{array}{l}\text { Short run } \\
\text { elasticity }\end{array}$ & $\begin{array}{l}\text { Long run } \\
\text { elasticity }\end{array}$ \\
\hline Maize hectarage $M\left({ }_{t-1}\right)$ & 0.7063 & 0.7802 \\
\hline Price of maize $\left(P_{m, t-l}\right)$ & 0.3467 & 0.4206 \\
\hline Price of sorghum $\left(P_{s g, t-1}\right)$ & 0.1859 & 0.2598 \\
\hline Quantity of seeds $\left(S_{m, t-1}\right)$ & 0.0170 & 0.0909 \\
\hline $\begin{array}{l}\text { Quatity of agrochemicals } \\
\left(F_{m, t-1}\right)\end{array}$ & 0.0546 & 0.1285 \\
\hline $\begin{array}{l}\text { Quantity of fertilizer } \\
\left(F E R_{t-1}\right)\end{array}$ & -0.0054 & 0.0685 \\
\hline Quantity of labour $\left(L_{m t-l}\right)$ & 0.0327 & 0.1066 \\
\hline Amount of rainfall $\left(R_{t-1}\right)$ & 0.0203 & 0.0942 \\
\hline Distance to market $\left(R_{I}\right)$ & -0.0037 & 0.0702 \\
\hline $\begin{array}{l}\text { Farmer's level of } \\
\text { education }\left(R_{2}\right)\end{array}$ & 0.0038 & 0.0777 \\
\hline Age $\left(R_{3}\right)$ & -0.0319 & 0.042 \\
\hline $\mathrm{HHmmP}\left(R_{4}\right)$ & -0.0283 & 0.0456 \\
\hline Coefficient of adjustment & -0.0739 & \\
\hline
\end{tabular}

Source: Author's calculation

The findings also showed the hectarage elasticity of supply response for maize to be 1.03 in the short run and 0.78 in the long run. This means that a $1 \%$ increase in land area cultivated for maize will lead to a more than proportionate increase in maize quantity supplied by $1.03 \%$ in the short run, and $0.78 \%$ in the long run. This finding corresponds with the findings of Oladejo and Ladipo (2012) who found the hectarage elasticity of supply response for maize to be 1.05 in Oyo and Osun States of Nigeria. The elasticity of price of competing crop (sorghum) was found to be low and negative as expected. The negative sign indicated that, as price of sorghum increases the quantity of maize supplied decreases as farmers turned towards producing more of sorghum. This was evident as framers' decision might be to maximize utility (either market driven or food need). This is in concordance with the result of Maiadua (2016) who reported the price of competing crop (sorghum) was low and negative in Nigeria.

Elasticities of quantity of seeds, fertilizer, labour, rainfall and age had positive but small, short and long run elasticities $(0.0829,0.1007$, $0.2197,0.0136$ and 0.0808 ) respectively. The implication of these is although maize supply responds to these variables but in low percentages. This is in accordance with the results of Ehirim et al. (2017) observed that rainfall increases actual output in the short run by $0.093 \%$ in Nigeria. Ogundari (2018) found that in the long run, maize supply responds significantly and positively to rainfall, and fertilizer use whereas short run supply responds only to fertilizer use in Nigeria.

With respect to land area, the own price elasticity of maize in the short run was 0.35 and 0.42 in the long run. That is a $1 \%$ increase in price of maize will result to a $0.35 \%$ and $0.42 \%$ increase in land share of maize in the short and long run respectively. This result therefore indicates that there disproportionate quick response of maize area to changes in price. In other words, this implies that maize producers can be price responsive. This finding agrees with the findings of Munyati et al. (2013) who reported that the price elasticity of acreage response with respect to the lagged market price for commercial farmers is inelastic in Zimbabwe. The elasticity of lagged farm size had elasticities of 0.706 and 0.780 (short and long run respectively), positive and between one and zero. This means that the farmers are slow in changing the planted areas, and it will take more than one year for this change to be effective. The result is in conformity with the findings of Alwan and ElHabbab (2002) who found that the wheat farm area planted in the previous year was positive and between one and zero in Jordan.

Estimated variables in the yield response function showed that the short run elasticities are greater than the long run values. This indicates that, variable inputs such as fertilizer, seeds and agrochemicals are factors whose quantities can be quickly adjusted to policy incentives. Therefore, if these variable inputs of production are available and devoted to agriculture, it can result to a substantial amount of output and yield in the short run and subsequently in the long run. On the other hand, all estimates (variables in hectarage response) long run estimates are greater than the short run values. The reason is that the response of price and non-price variables to changes in agricultural supply is low in the short run because most factors of production are fixed in the short run. Land, capital, and labour account for a greater percentage of agricultural production, therefore, these resources must be devoted to agriculture to obtain a substantial amount of agricultural output. This is difficult in the short run considering the relative fixity of these resources; land availability cannot be altered without considerable investment, supplies of capital cannot increase rapidly, agricultural technology cannot be increased without considerable amount of capital investment and labour availability cannot change without population growth or migration among sectors or regions (Utuk, 2014).

\section{Factors influencing Seed, Fertilizer, Agrochemicals and Labour Demand}

Tables 6, 7, 8 and 9 present parameter estimates for seeds, fertilizer, agrochemicals and labour demand, respectively. The result of the estimation for seed equation (Table 6) showed that only the coefficient cost of agrochemical was statistically significant at $1 \%$ and was less than unity $(0.87)$, but all other variables were not significantly different from zero. This means that agrochemicals have a significant positive impact on seed demand. Seed treatment with insecticide has been determined to be an economically feasible technology solution to problems in rainfed maize production. The use of agrochemicals in maize production in Nigeria has 
increased over the years. Banful et al. (2009) reported that although modern input use may be relatively low in aggregate, it is not equally low particularly regarding the use of agrochemicals in the country. The demand for seeds with respect to its own price is positive but not significantly different from zero. Although the own price of seeds does not significantly affect the quantity demanded, Kormawa et al. (2000) indicated that seeds give the most dramatic and most costeffective return on investment.

The result of the fertilizer demand equation is shown in Table 7. The estimated equation shows that the parameter estimate associated with cost of agrochemicals $(0.8718)$ has a significant positive impact on quantity of fertilizer demanded. Thus, the higher the price of agrochemical the higher the demand for fertilizer. Adamu (2000) stated that improvement in management (timeliness; best use of fertilizer, crop protection measures and equipment) provided $50 \%$ of the productivity gains in agriculture. A similar result was obtained by Muhammed and Bila (2014) on their study on effects of price incentives on supply of castor seed in Nigeria.

On the other hand, amongst the non-price factors included in the analysis, the coefficient of land size showed significant positive relationship with quantity of fertilizer demanded. That is, the bigger the farm size, the higher the demand for fertilizer. This confirms empirical and theoretical expectations. It is noteworthy to mention that the own price of fertilizer does not significantly affect fertilizer demand but remains positive. Analogous to this result is the findings of Rajapaksha and Karunagoda (2009), which stated that changes in the prices of fertilizer do not have a significant effect on fertilizer demand in Sri Lanka.

All parameters remained non-significant in the equations for the demand of agrochemicals, shown in Table 8. Notably, the own price of agrochemicals has a negative relationship with its demand, that is a decrease in the price of agrochemical will increase its demand by 0.0962 .

Table 6: Price and non-price factors affecting seeds demand

\begin{tabular}{lccc}
\hline Variables & $\begin{array}{c}\text { Regression } \\
\text { coefficient }\end{array}$ & $\begin{array}{c}\text { Std. } \\
\text { error }\end{array}$ & $\begin{array}{c}t \text { - } \\
\text { value }\end{array}$ \\
\hline Constant & $3.3093 * * *$ & 0.3300 & 10.03 \\
$L N P_{f}$ (cost of fertilizer) & 0.1342 & 0.2523 & 0.53 \\
$L N P_{l}$ (cost of labour) & 0.0953 & 0.2482 & 0.38 \\
$L N P_{s}$ (cost of seeds) & 0.0076 & 0.2584 & 0.03 \\
$L N P_{a c}$ (cost of agrochemicals) & $0.8718 * * *$ & 0.2614 & 3.33 \\
$L N H_{m, t}$ (land size) & 0.1690 & 0.2819 & 0.6 \\
$L N R_{I}$ (distance to market) & 0.0834 & 0.2641 & 0.32 \\
$L N R_{2}$ (farmer's education level) & -0.1344 & 0.2608 & -0.52 \\
\hline$S O u r c:$ Field Survey, 2017;***significt
\end{tabular}

Source: Field Survey, 2017; ***significant at 1\%
Table 7: Price and non-price factors affecting fertilizer demand

\begin{tabular}{lccc}
\hline Variables & $\begin{array}{c}\text { Regression } \\
\text { coefficient }\end{array}$ & $\begin{array}{c}\text { Std. } \\
\text { error }\end{array}$ & $\begin{array}{c}t \text { - } \\
\text { value }\end{array}$ \\
\hline Constant & $6.2817^{* * *}$ & 0.2511 & 25.02 \\
$L N P_{f}$ (cost of fertilizer) & 0.1465 & 0.1920 & 0.76 \\
$L N P_{l}$ (cost of labour) & -0.2078 & 0.1888 & -1.10 \\
$L N P_{s}$ (cost of seeds) & -0.0730 & 0.1966 & -0.37 \\
$L N P_{a c}$ (cost of agrochemicals) & $0.5104^{* *}$ & 0.1989 & 2.57 \\
$L N H_{m, t}$ (land size) & $0.4782^{* *}$ & 0.2145 & 2.23 \\
$L N R_{l}$ (distance to market) & -0.0595 & 0.2010 & -0.30 \\
$L N R_{2}$ (farmer's education level) & & 0.1985 & 0.93 \\
\hline
\end{tabular}

Source: Field Survey, 2017;

$* * *$ significant at $1 \% ; * *$ significant at $5 \%$

Table 8: Price and non-price factors affecting agrochemicals demand

\begin{tabular}{lccc}
\hline Variables & $\begin{array}{c}\text { Regression } \\
\text { coefficient }\end{array}$ & $\begin{array}{c}\text { Std. } \\
\text { error }\end{array}$ & $\begin{array}{c}t \text { - } \\
\text { value }\end{array}$ \\
\hline Constant & $1.9527^{* * *}$ & 0.1889 & 10.34 \\
$L N P f$ (cost of fertilizer) & 0.0410 & 0.1444 & 0.28 \\
LNPl (cost of labour) & 0.1548 & 0.1420 & 1.09 \\
$L N P S$ (cost of seeds) & 0.0016 & 0.1479 & 0.01 \\
$L N P a c$ (cost of agrochemicals) & -0.0962 & 0.1496 & -0.64 \\
$L N H_{m, t}$ (land size) & 0.0953 & 0.1614 & 0.59 \\
$L N R_{I}$ (distance to market) & 0.0371 & 0.1512 & 0.25 \\
$L N R_{2}$ (farmer's education level) & -0.1100 & 0.1493 & -0.74 \\
\hline
\end{tabular}

Source: Field Survey, 2017; ***significant at 1\%

In contrast, all variables were positively related to labour demand by the farmers (Table 9). The implication of this is that a $1 \%$ increase in prices of fertilizer and seeds will marginally increase labour demand correspondingly by $0.0923 \%$ and $0.001 \%$. Nevertheless, cost of agrochemicals was significant at $1 \%$ level of probability. That is a $1 \%$ increase in the cost of agrochemical will increase the demand for labour by $0.2674 \%$. This is, expected because the use of agrochemical will substitute the need for traditional manual labour. This might be because instead of using more labour in general maize production practice, agrochemicals can be used to reduce intensive labour input. This agrees with the results of Wijetunga (2016). Among the fixed inputs, only farm size was found to have positive statistical significance on the demand for labour. Increases in maize farm-land area can increase the demand for all variable inputs of production in the studied area. This outcome is in consonant with the result of Olwande et al. (2009). 
Table 9: Price and non-price factors affecting labour demand

\begin{tabular}{lccc}
\hline Variables & $\begin{array}{c}\text { Regression } \\
\text { coefficient }\end{array}$ & $\begin{array}{c}\text { Std. } \\
\text { error }\end{array}$ & $\begin{array}{c}t \text { - } \\
\text { value }\end{array}$ \\
\hline Constant & $3.2457 * * *$ & 0.1201 & 27.02 \\
$L N P_{f}$ (cost of fertilizer) & 0.0923 & 0.0918 & 1.00 \\
$L N P_{l}$ (cost of labour) & 0.0883 & 0.0903 & 0.98 \\
$L N P_{s}$ (cost of seeds) & 0.0001 & 0.0941 & 0.01 \\
$L N P_{a c}$ (cost of agrochemicals) & $0.2674 * * *$ & 0.0952 & 2.81 \\
$L N H_{m, t}$ (land size) & $0.2204 * *$ & 0.1026 & 2.15 \\
$L N R_{I}$ (distance to market) & 0.0975 & 0.0961 & 1.01 \\
$L N R_{2}$ (farmer's education level) & 0.1348 & 0.0949 & 1.42
\end{tabular}

Source: Field Survey, 2017;

$* * *$ significant at $1 \% ; * *$ significant at $5 \%$

\section{CONCLUSION AND RECOMMENDATION}

The study delineated modified Nerlove model and input demand equations. The result of the analysis of the supply response models showed that in all estimates (variables in yield and hectarage response) long run estimates are greater than the short run values. The main findings indicated that both the short and long run supply elasticities were inelastic, signifying that Kaduna State maize farmers are relatively unresponsive to output prices. The own price short run elasticity was 0.085 and long run elasticity was 0.204 for the yield response, while own price short run elasticity was 0.37 and 0.42 in the long run for the hectarage response. The elasticity of lagged farm size had elasticities of 0.706 and 0.780 (short and long run, respectively), positive and between zero and one.

Based on these findings, it is concluded that maize producers in the study area were less sensitive to changes in price and non-price incentives in the previous year. The low magnitude of elasticity is thus an indication that low real farm prices were not the most important reasons for low productivity or supply particularly in rural areas. Rather, the most critical issues were lack of improved production technology, poor capital investment, land unavailability or poor land tenure system and poor policy incentives. Hence the following recommendations are made: there is a need to formulate a State specific policy on agricultural research and extension, while ensuring adequate policies on prices of improved seed varieties, agrochemicals, fertilizer and labour. Since extension services are still being largely provided by government efforts, the government is advised to dissolve the agricultural extension service system to local governments. Under which the extension program planning, management, and co-financing responsibilities are transferred to the LGAs. This will allow agricultural extension system to be more location specific, promoting bottom-up planning with local participation, co-financing, and better monitoring of agricultural development programs.

\section{REFERENCES}

Abrar S., Morrissey O. and Rayner A. (2004). Aggregate agricultural supply response in Ethiopia: A farmlevel analysis. J. Int. Dev., 164, 605-620

Adamu H. (2000). National consultation on developing sustainable agricultural input supply system in Nigeria. Keynote Address at Stakeholders' Workshop, Abuja, Nigeria

Ajani E.N. and Igbokwe E.M. (2014). A review of agricultural transformation agenda in Nigeria: The case of public and private sector participation. Res. J. Agric. Environ. Manag., 3 (5), 238-245

Alabi O.O. (2008). Comparative analysis of industrial demand and supply for maize and sorghum in Kaduna and Kano states of Nigeria. J. Prod. Technol. Agric., 42, 14-23

Alwan K.H. and El-Habbab M.S. (2002). Estimating supply response function for wheat: A case study. Agric. Sci., 71, 29-35

Owoeye R.S., Adetule F.S. and Ajayi G.T. (2017). Analysis of productive resources of maize crop among farming households in Ekiti state, Nigeria. Int. J. Agric. Econ., 25, 142-148

Askari H. and Cummings J.T. (1977). Estimating agricultural supply response with the Nerlove model: A survey. Int. Econ. Rev., 182, 257-292

Babu S.C., Gajanan S.N. and Sanayal P. (2014). Effects of commercialization of agriculture (shift from traditional crop to cash crop) on food consumption and nutrition-application of chi-square statistics. In: S.C. Babu, S.N. Gajanan and P. Sanayal (eds.), Food Security, Poverty and Nutrition Policy Analysis: Statistical Methods and Applications (pp. 63-91). Amsterdam, Academic Press

Banful A.B., Nkonya E. and Oboh V. (2009). Constraints to fertilizer use in Nigeria: Perspectives and insights from the Agricultural Extension Service Brief No. 6. International Food Policy Research Institute, Washington DC

Boughton D., Mather D., Barrett C.B., Benfica R., Abdula D., Tschirley D. and Cunguara B. (2007). Market participation by rural households in a lowincome country: An asset-based approach applied to Mozambique. Faith Econ., 50 (2007), 64-101

Braulke M. (1982). A note on the Nerlove model of agricultural supply response. Int. Econ. Rev., 23, 241-244

Diebold F.X. and Lamb R.L. (1997). Why are estimates of agricultural supply response so variable? In: Ball V.E., Moss C.B., Erickson K.W. et al. (eds.), Modelling Supply Response in a Multiproduct Framework Revisited: The Nexus of Empirics and Economics. http://ageconsearch.umn.edu/handle/21981 Accessed Nov., 2017

Duniya K.P. (2014). Productivity of Hungry Rice (Digitaria exilis) in Selected Local Government Areas of Kaduna State, Nigeria. MSc Thesis, Ahmadu Bello University, Zaria, Nigeria, p. 60

Ehirim N., Okoro U., Nwauwa L., Onwuagba I. and Mgbeojirikwe C. (2017). Soybean supply response to price and non-price factors in Nigeria: Implications for food security. Asian J. Agric. Ext. Econ. Sociol., 153, $1-10$

Farooq U., Young T., Russel N. and Iqbal M. (2001). The supply response of basmati rice growers in Punjab Pakistan: Price and non-price determinants. $J$. Int. Dev., 132, 227-237 
Federal Ministry of Agriculture and Rural Development (2011). Agricultural transformation agenda: We will grow Nigeria's agricultural sector. FMARD. Available at unaab.edu.ng/attachments/agriculturaltransformation-blueprint.pdf (Accessed $20^{\text {th }}$ January, 2017)

Griliches Z. (1960). Measuring input in agriculture: A critical survey. J. Farm Econ., 42, 1411-1427

Hallam D. and Zanoli R. (1992). Error correction models and agricultural supply response. Europ. Rev. Agric. Econ., 2, 111-120

Kavinya P. and Phiri M.A.R. (2014). Maize hectarage response to price and non-price incentives in Malawi. J. Agric. Sci., 43, 142-151

Kormawa P., Okorji E. and Okechukwu R. (2000). Assessment of Seed-Sub Sector Policy in Nigeria, IITA Ibadan Nigeria, p. 73

Kwanashie M., Ajilima I. and Garba A. (1998). The Nigerian Economy: Response of Agriculture to Adjustment Policies. African Economic Research Consortium Nairobi Kenya, Research Paper No. 78

Leaver R. (2004). Measuring the supply response function of tobacco in Zimbabwe. Agrekon, 431, 113-131

Leonardo W., van de Ven G., Udo H.M.J., Kanellopoulos A., Sitoe A.A. and Giller K. (2015). Labour not land constrains agricultural production and food self-sufficiency in maize-based smallholder farming systems in Mozambique. Food Secur., 74, 857-874

Maiadua S.U. (2016). Growth and Supply Response for Some Selected Food Crops in Nigeria. PhD Dissertation, Prof Jayashankar Telangana State Agricultural University, India

Muhammed S.T. and Bila Y. (2014). Effects of price incentives on supply of castor seed in Nigeria: A profit function analysis. Emperical Econ. Lett., 1312, 1295-1305

Mulford M.R. (2013). Smallholder Market Participation and Welfare Effects: Evidence from the Kenya Diary Sector. MSc Thesis, Cornell University, USA

Munyati V., Mugabe D., Chipunza N., Mafuse N., Chagwiza G. and Musara J. (2013). An econometric approach to ascertain sorghum supply response in Zimbabwe. Emperical Econ. Lett., 847, 6034-6038

NAERLS and FMARD (2017). Agricultural performance survey of 2015 wet season in Nigeria. National Agricultural Extension and Research Liaison Service, Zaria, Nigeria, and Federal Ministry of Agriculture and Rural Development, Abuja, Nigeria

National Population Commission (2006). Population census of the Federal Republic of Nigeria Abuja Nigeria

Nerlove M. (1958). The Dynamic of Supply: Estimation of Farmers' Response to Prices, The John Hopkins University Press, London, p. 267

Nerlove M. (1979). The dynamics of supply: Retrospect and prospect. Am. J. Agric. Econ., 61 (5), 874-888

Nkang N.M., Ndifan H.N. and Edet E.O. (2007). Maize supply response to changes in real prices in Nigeria: A vector error correction approach. Agric. J., 23, $419-425$
Obayelu O.A. and Ebute S. (2016). Assessment of cassava supply response in Nigeria using vector error correction model VECM. Agricultura, 131 (2), 22-27

Obike K.C., Idu M.A. and Aigbokie S.O. (2016). Labour productivity and resource use efficiency amongst smallholder cocoa farmers in Abia state, Nigeria. Agro-Science, 15 (3), 1-8

Ogazi C.G. (2009). Rice output supply response to the changes in real prices in Nigeria: An autoregressive distributed lag model approach. J. Sustain. Dev. Afr., 114, 83-100

Ogundari K. (2018). Maize supply response to price and non-price determinants in Nigeria: Bounds testing approach. Int. J. Oper. Res., 25, 1537-1551

Oladejo J.A. and Ladipo O.O. (2012). Supply analysis for maize in Oyo and Osun states of Nigeria. Int. $J$. Life Sci. Pharma. Res., 22, L8-L18

Olwande J., Ngigi M. and Nguy W. (2009). Supply responsiveness of maize farmers in Kenya: A farmlevel analysis. Proc. $24^{\text {th }}$ International Conference of Agricultural Economist, Beijing, China

Omotesho K., Muhammad-Lawal A. and Iyiowu G.O. (2016). Analysis of agro-chemical inputs use in maize production among small-scale farmers in Iwo local government Osun state, Nigeria. Int. J. Agric. Manag. Dev., 61, 43-50

Rajapaksha R.D.D.P. and Karunagoda K.S. (2009). Fertilizer demand for paddy cultivation in Sri Lanka with special reference to fertilizer subsidy program. Sri Lankan J. Agric. Econ., 132, 25-38

Rao B.B. (2007). Cointegration for the Applied Economics $\left(2^{\text {nd }}\right.$ ed.), Palgrave Macmillan, New York, USA, p. 57

Rudaheranwa N., Bategeka L., Banga M. and Mukungu A. (2003). Supply response of selected export commodties in Uganda. Kampala: Economic Policy Research Centre (EPRC). Retrieved from: documents.world bank.org/curated/.../794020JRN0Rice00Box0379855 B00OUO090.p

Shehu U.A., Ibrahim A., Hassan T. and Bello M. (2017). Analysis of resource use efficiency in small-scale maize production in Tafawa-Balewa local government of Bauchi state, Nigeria. Agrosearch, 10 (2), 29-35

Shoko R.R., Chaminuka P. and Belete A. (2016). Estimating the supply response of maize in South Africa: A Nerlovian partial adjustment model approach. Agrekon, 553, 237-253

United States Department of Agriculture (2013). Nigerian corn production by year. http://www.index mundi.com/ agriculture? country=ngandcom (Accessed Jan., 2018)

Utuk I.O. (2014). Aggregate agricultural output supply response in Akwa Ibom state, Nigeria: An application of the Nerlovian adjustment model. $J$. Agric. Vet. Sci., 79, 24-33

Wijetunga C.S. (2016). Rice production structures in Sri Lanka: The normalized translog profit function approach. Asian J. Agric. Rural Dev., 62, 21-35 